\title{
Productive Consequences of Fasting Neonatal Chicks of Different Genetic Constitutions for Growing
}

Author(s)
Gonzales $\mathrm{E}^{1}$
Stringhini $\mathrm{JH}^{2}$
Dahlke $\mathrm{F}^{3}$
Cunha WCP
Xavier SAG ${ }^{5}$
1 Voluntário Professor Livre Docente.
Faculdade de Medicina Veterinária e
Zootecnia, UNESP. Botucatu, SP, Brasil.
2 Professor Associado I, DPA/EV-UFG. Goiânia,
GO, Brasil.
3 Professor Adjunto, DZ/SCA-UFPR. Curitiba,
PR, Brasil.
4 Médico Veterinário, Mestre. Avibal-Sadia.
Buriti Alegre, GO, Brasil.
5 Médica Veterinária, Mestre, Poli-Nutre
Alimentos Ltda. Osasco, SP, Brasil.

Mail Address

Elisabeth Gonzales

Rua Justino Miranda Camargo, 1386

18.610-130. Botucatu, SP, Brazil.

E-mail: elisa.gonzales@uol.com.br

\section{Keywords}

Chicks, fasting, neonatal, performance, yolk sac.

\section{Acknowledgments}

The authors thank CNPq and FAPESP for their financial support.

\section{ABSTRACT}

The study was designed to evaluate the productive consequences of fasting neonatal chicks obtained from strains genetically divergent for growing. Four hundred eight chicks from three strains, 160 from breeders selected for high growth rate and excellent feed conversion ratio (Cobb 500), 160 from breeders not selected for fast growth (JA57), and 160 from a white egg layer strain (Hy-Line W98) were allotted in a 3 (strain) $\times 2$ (fasting period -8 and $36 \mathrm{~h}$ after hatching) factorial arrangement with 5 replicates of 16 chicks each. Immediately after hatching, all chicks had similar $(P>0.05)$ relative yolk sac weights (14.13\%, 14.50\%, and $15.49 \%$ for Hy-Line, Cobb, and JA57, respectively). The yolk sac retractions were proportionally higher for Cobb and JA57 chicks up to $144 \mathrm{~h}$ (6 days) after placement, but were not influenced by $36 \mathrm{~h}$ of feed fasting. At 7 and 14 days of age only Cobb chicks had their body weight and weight gain significantly $(P<0.05)$ depressed by $36 \mathrm{~h}$ feed fasting after hatching. Results indicate that broiler chicks with intense initial growth rates (Cobb 500) need an outstanding nutritional supply, either from exogenous (feed) or endogenous (residual yolk) sources, to achieve a final weight compatible with their genetic constitution. For slow-growing chicks (Hy-Line), nutritional supplementation via yolk sac seems to be more important than exogenous supply (feed) of nutrients during the neonatal period.

\section{INTRODUCTION}

Factors that regulate growth rate of chicks after a period of feed restriction are partially related to the adaptation of the gastrointestinal tract, such as weight increase, increase in the activity of digestive enzymes, and decrease in the time of digesta retention (Nir et al., 1993). More attention has been recently given to the time that the chicks remain without feed after hatching, which influences the performance of broilers at slaughter age (Gonzales et al., 2000, 2003). Similar to the phenomenon of yearly feed restriction, feed fasting results in poor development of supply organs and tissues of the gastrointestinal tract (Uni et al., 1998).

It is known that the growth of neonatal chicks before exogenous feeding (feed) depends on the nutritional elements absorbed from the residual yolk sac (Noy \& Sklan, 1998). However, as previously mentioned, delays in placement and feeding of broiler chicks cause productive losses later on, at 42 days of age (Gonzales et al., 2003). Early feeding after hatching, as compared to delayed feeding, appears to stimulate yolk utilization (Noy \& Sklan, 1998; Speake et al., 1998).

According to Nitsan et al. (1991), the size of yolk sac of birds selected for high growth rate (broiler chicks) is smaller than those birds that present slow development, such as White Leghorn birds. These facts indicate 


\section{Gonzales E, Stringhini JH, Dahlke F, Cunha WCP, Xavier SAG}

Productive Consequences of Fasting Neonatal Chicks of Different Genetic Constitutions for Growing that the supplementation of nutrients via residual yolk is not sufficient to support the extremely high growth rate of broiler chicks during the initial post-hatch phase. Thus, the use of residual yolk and the need of exogenous nutrition (ration) of neonatal chicks from divergent background for growing may be different and related to at least two factors - the genetic bird constitution and the feed fast time immediately after hatching.

This study was designed to evaluate the productive consequences of chickens obtained from strains genetically divergent in growth rate (Cobb-500, JA57, and $\mathrm{Hy}$-Line W48) and subjected to a period of either 8 or 36 h of feed fasting after hatching.

\section{MATERIAL AND METHODS}

Chicks were obtained from three breeder strains: Cobb 500, selected for high growth rate and excellent feed conversion ratio; JA57 (naked-neck broiler), not selected to grow very fast; and Hy-Line W98, light bird selected for egg production. Mean weights of the incubated eggs for chick production were $63.7 \mathrm{~g}, 72.0 \mathrm{~g}$ and $73.0 \mathrm{~g}$ for Hy-Line, Cobb, and JA57 breeders, respectively.

Chicks were allotted eight hours after hatching to a randomized block experimental design with a $3 \times 2$ factorial arrangement (3 strains: Cobb 500, JA57, and Hy-Line; and 2 fasting periods after hatching - 8 and 36h), with 5 replicates of 16 chicks each, totaling 6 treatment groups, 30 experimental units, and 480 chicks, being 160 of each strain.

Birds were distributed in three batteries of five floors each divided in two boxes. When necessary, heat was provided during the post-hatch rearing period (1 to 14 days) using infrared lamps placed in front of the batteries.

Immediately after placement ( 8 hours after hatching), all birds had ad libitum access to water. At this moment, half of the birds of each strain were fed. The other half was fed only $28 \mathrm{~h}$ after placement (36h after hatching).

Feed was supplied in mash form, and formulated to contain $3050 \mathrm{kcal} / \mathrm{kg} \mathrm{ME}, 0.57 \%$ Met, $0.94 \%$ Met+Cys, $1.20 \% \mathrm{Ca}$, and $0.46 \%$ available $\mathrm{P}$.

After hatching, ten birds of each strain were weighed, killed by cranial traumatism, and had their yolk sacs excised and weighed. The same sacrifice procedure and residual yolk sac evaluations of two experimental birds per replicate were carried out at 24, 48, 72, 96, 120 and 144h after placement. Body weight, weight gain, and mortality index of the experimental groups were recorded on the 7th and the 14th experimental days.

Results were statistically processed using General Linear Model procedures of SAEG (1999) computational program. Data were submitted to analysis of variance (ANOVA) according to a block experimental design with a 3 × 2 factorial arrangement. When necessary, differences among means were separated by Tukey's test $(p<0.05)$.

\section{RESULTS AND DISCUSSION}

Chicks from the three strains had similar relative yolk sac weights immediately after hatching despite the differences in body weight (Table 1). Cobb neonatal chicks presented the highest body and yolk weights, which were different from those of Hy-Line and JA57 chicks. However, yolk sac percentage relative to chick body weight was similar among strains $(14.50 \%$, $15.49 \%$, and $14.13 \%$ for Cobb, JA57, and Hy-Line, respectively), which is consistent with the results obtained by Chamblee et al. (1992).

\begin{tabular}{|c|c|c|c|}
\hline \multirow[b]{2}{*}{ Strain } & \multicolumn{3}{|c|}{ Yolk sac weight, } \\
\hline & Body weight, $\mathrm{g}$ & $\mathbf{g}$ & $\% 1$ \\
\hline Cobb 500 & $47.4 a$ & 6.88 & 14.50 \\
\hline JA57 & $43.1 b$ & 6.70 & 15.49 \\
\hline Hy-Line W98 & $44.5 b$ & 6.30 & 14.13 \\
\hline
\end{tabular}

1 - Relative to body weight. a, b - Values sharing no common superscripts are statistically different by Tukey's test $(P<0.05)$.

No statistical interaction ( $P>0.05)$ between strain and feed fasting effects was observed for yolk sac retractions (Table 2) up to $144 \mathrm{~h}$ ( 6 days) after placement. Independently of the fasting period, a normal standard curve of residual yolk sac reduction as a function of post-hatching time was observed. Only small amount of residual yolk was present up to $144 \mathrm{~h}$ after placement in all chicks of the three evaluated strains. However, residual yolk utilization was proportionally higher in Cobb chicks as compared to Hy-Line birds. JA57 chicks presented intermediate yolk sac retraction. Holding the birds for $36 \mathrm{~h}$ without feed did not influence the proportional use of the yolk sacs. However, other studies indicated that fasting depressed yolk utilization (Noy \& Sklan, 1998; Gonzales et al., 2003). This difference may be attributed to the high coefficient of variation observed, which is characteristic of this kind of measurement. 


\section{Gonzales E, Stringhini JH, Dahlke F, Cunha WCP, Xavier SAG}

\begin{tabular}{|c|c|c|c|c|c|c|c|c|c|c|c|c|}
\hline \multirow[b]{2}{*}{ Strain } & \multicolumn{2}{|c|}{$24 \mathrm{~h}$} & \multicolumn{2}{|c|}{$48 \mathrm{~h}$} & \multicolumn{2}{|c|}{$72 \mathrm{~h}$} & \multicolumn{2}{|c|}{$96 \mathrm{~h}$} & \multicolumn{2}{|c|}{$120 \mathrm{~h}$} & \multicolumn{2}{|c|}{$144 \mathrm{~h}$} \\
\hline & 9 & $\%$ & g & $\%$ & g & $\%$ & g & $\%$ & g & $\%$ & g & $\%$ \\
\hline Cobb 500 & $5.29 a$ & $11.49 a$ & 3.06 & 5.81 & 1.63 & $2.57 \mathrm{~b}$ & $0.98 b$ & $1.37 c$ & 0.87 & $1.04 b$ & 0.42 & $0.40 \mathrm{~b}$ \\
\hline JA57 & $3.76 b$ & $9.13 b$ & 2.76 & 6.10 & 1.73 & $3.36 b$ & $1.51 \mathrm{a}$ & $2.54 b$ & 1.25 & $1.80 a$ & 0.33 & $0.43 b$ \\
\hline $\begin{array}{l}\text { Hy-Line W98 } \\
\text { Fast period }\end{array}$ & $5.03 a$ & $12.48 \mathrm{a}$ & 3.00 & 7.37 & 2.35 & $5.29 a$ & $1.79 a$ & $3.79 a$ & 1.00 & $1.88 \mathrm{a}$ & 0.49 & $0.84 a$ \\
\hline $8 \mathrm{~h}$ & 4.63 & 10.71 & 3.02 & 6.23 & 1.80 & 3.33 & 1.43 & 2.56 & 1.00 & 1.43 & 0.39 & 0.52 \\
\hline $36 \mathrm{~h}$ & 4.75 & 11.36 & 2.87 & 6.62 & 2.01 & 4.15 & 1.42 & 2.57 & 1.07 & 1.72 & 0.43 & 0.60 \\
\hline$C V$ & 20.68 & 17.80 & 21.52 & 22.41 & 38.39 & 36.97 & 32.30 & 30.58 & 47.54 & 50.56 & 56.38 & 64.81 \\
\hline
\end{tabular}

$a, b, c-$ Values sharing no common letters are statistically different by Tukey's test $(P<0.05)$.

Significant interactions $(P<0.05)$ between feed fasting period $x$ chick strain were observed for body weight and weight gain (Table 3 ). As expected, consistent weight gain of the Cobb chicks at 7 and 14 days of rearing was registered (Table 3), and independently of fasting, they presented the highest body weight and weight gain, followed by JA57 and Hy-Line birds. However, only Cobb chicks had their body weight and weight gain depressed by $36 \mathrm{~h}$ of feed fasting. Body weights and weight gains of Hy-Line and JA57 chicks were not affected by the long period of fasting. In fact, Hy-Line birds held without feed for $36 \mathrm{~h}$ after hatching showed higher, despite not significant, weight gain than their $8 \mathrm{~h}$-fasted counterparts. Confirming other studies (Gonzales et al., 2000, 2003), delaying access to feed for $36 \mathrm{~h}$ after hatching impaired body weight and weight gain of broiler chicks selected for fast growth.

Observing the relative weight gain curve of the 8hfasted chicks up to 6 days after placement, a clear difference in favor of Cobb chicks for growth was verified (Figure 1). This figure also shows that Hy-Line chicks had negative weight gain at 24 and $48 \mathrm{~h}$ after hatching, and grew very slowly from the 3rd to the 6th day post-hatching, suggesting that these birds did not respond enough to the supply of feed.

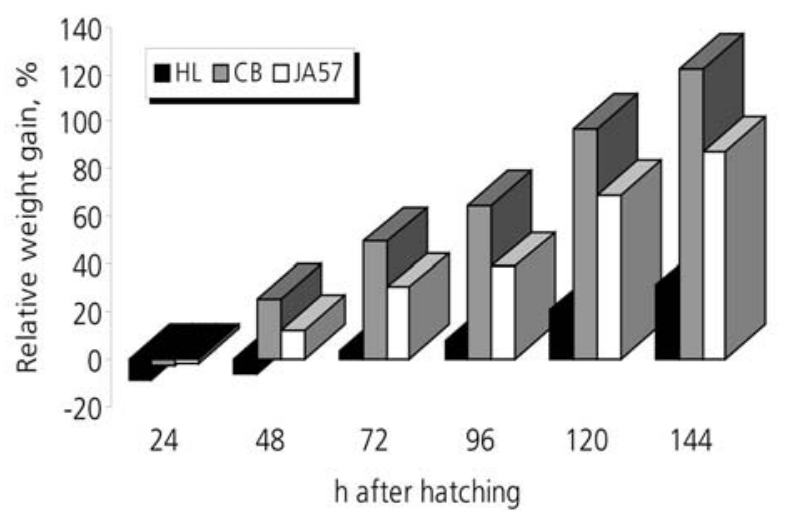

Figure 1 - Relative wheight gain of chickens of different genetic constitutions for growth after hatching. $\mathrm{HL}=\mathrm{Hy}$-Line W98; $\mathrm{CB}=$ cobb 500; JA57 = Nacked neck JA57.

Mortality index was low, and did not differ among the treatment groups (Table 4).

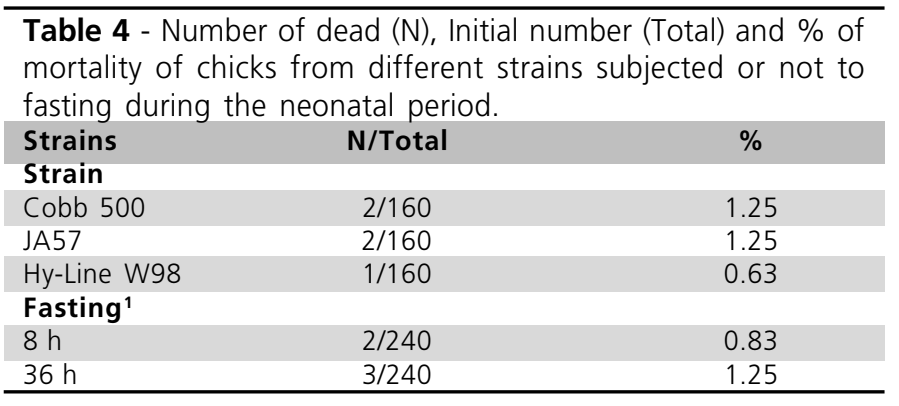

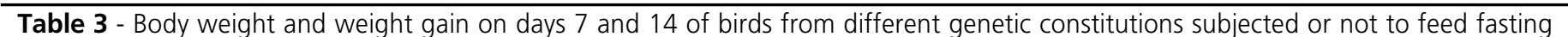
after hatching.

\begin{tabular}{|c|c|c|c|c|c|c|}
\hline \multirow[b]{2}{*}{ Fast period } & \multicolumn{3}{|c|}{ Body weight, g } & \multicolumn{3}{|c|}{ Weight gain, g } \\
\hline & $8 \mathrm{~h}$ & $36 \mathrm{~h}$ & Mean & $8 \mathrm{~h}$ & $36 \mathrm{~h}$ & Mean \\
\hline \multirow{2}{*}{\multicolumn{7}{|c|}{1 to 7 days }} \\
\hline & & & & & & \\
\hline Cobb 500 & $139.8 \mathrm{~A} \mathrm{a}$ & $121.8 \mathrm{~A} \mathrm{~b}$ & 130.8 & $91.7 \mathrm{~A} \mathrm{a}$ & $73.7 \mathrm{~A} \mathrm{~b}$ & 82.7 \\
\hline JA57 & $96.7 \mathrm{~B}$ & $90.1 \mathrm{~B}$ & 93.4 & $53.6 \mathrm{~B}$ & $47.0 \mathrm{~B}$ & 50.3 \\
\hline Hy-Line W98 & $64.5 \mathrm{C}$ & $66.0 \mathrm{C}$ & 65.3 & $22.0 \mathrm{C}$ & $23.8 \mathrm{C}$ & 22.9 \\
\hline \multicolumn{7}{|c|}{1 to 14 days } \\
\hline Strain & & & & & & \\
\hline Cobb 500 & $347.9 \mathrm{~A} \mathrm{a}$ & $267.5 \mathrm{~A} \mathrm{~b}$ & 307.7 & $299.8 \mathrm{~A}$ a & $219.4 \mathrm{~A} \mathrm{~b}$ & 259.6 \\
\hline JA57 & 197.3 B & 181.5 B & 189.4 & $154.2 \mathrm{~B}$ & $138.3 \mathrm{~B}$ & 146.3 \\
\hline Hy-Line W98 & $111.2 \mathrm{C}$ & $115.2 \mathrm{C}$ & 113.2 & $68.7 \mathrm{C}$ & $73.0 \mathrm{C}$ & 70.8 \\
\hline Mean & 218.8 & 188.1 & & 174.2 & 143.6 & \\
\hline
\end{tabular}

A, B, C - In a column, no common capital letters indicate significant strains effects (Tukey's test, $P<0.05$ ). $a, b-$ In a row, no common letters indicate significant feed fast period effects ( $F$ test,$P<0.05)$. 
The results of this experiment indicate that chicks with intense initial growth rates (Cobb 500) need an outstanding nutritional supply, either from exogenous (feed) or endogenous (residual yolk) sources, to achieve a final weight compatible with their genetic constitution. For slow-growing chicks (Hy-Line), the nutritional supplementation via yolk sac seems more important than the exogenous source (feed) during the neonatal period.

\section{REFERENCES}

Chamblee TN, Brake JD, Schultz CD, Thaxton JP. Yolk sac absorption and initiation of growth in broilers. Poultry Science 1992; 71:18111816.

Gonzales E, Leandro NSM, Varoli Jr JC, Takita TS, Loddi MM. O tempo de jejum do neonato e a restrição alimentar quantitativa influenciando a produtividade de frangos de corte na idade de abate. Revista Brasileira de Ciência Avícola 2000; (Supl 2):4.

Gonzales E, Kondo N, Saldanha ESPB, Loddi MM, Careghi C, Pizzolante CC, Decuypere E. Performance and p hysiological parameters of broiler chickens subjected to fasting on the neonatal period. Poultry Science 2003; 82:1250-1256.

Nir I, Nitsan Z, Mahagna M. Comparative growth and development of the digestive organs and of some enzymes in broiler and egg type chicks after hatching. British Poultry Science 1993; 34:523532.

Nitsan Z, Dunnington EA, Wiegel PB. Organ growth and digestive enzyme levels to fifteen days of age in lines of chickens differing in body weight. Poultry Science 1991; 70:2040-2048.

Noy Y, Sklan D. Yolk utilization in the newly hatched pouts. British Poultry Science 1998; 39:446-451.

SAEG - Sistemas de Análises Estatísticas [CD-ROM]. Viçosa: Fundação Arthur Bernardes: UFV; 1999.

Speake BK, Noble R, Murray A. The utilization of yolk lipids by the chick embryo. World's Poultry Science Journal 1998; 54:319-334.

Uni Z, Ganot S, Sklan D. Posthatch development of mucosal function in the broiler small intestine. Poultry Science 1998; 77:75-82. 